\title{
Peran Majelis dalam Pemberdayaan Ekonomi di Gereja Toraja Jemaat Imanuel Botang
}

\author{
Markus Sakke Pauranan \& Jermia Limbongan \\ Intitut Agama Kristen Negeri Toraja \\ Email : markuspauranan93@gmail.com
}

\begin{abstract}
Imanuel Botang congregation had resources both human resources and natural resources that were quite abundant, but had not been managed optimally. Seeing these conditions, researchers were interested in researching the role of church assemblies in the economic empowerment of congregations by focusing research on economic empowerment activities in the field of horticultural agriculture and chicken and pig farming. This research was designed according to qualitative research. Qualitative research aims to find out the role of church assemblies in the economic empowerment of congregations. Data collection techniques were carried out through library research and field research through observation and interview. The study was conducted at the Congregation of Emmanuel Botang from September to November 2020. The results showed the role of the Church Assembly in empowerment is as a consultant and empowerment but this is still not realized because it does not fully understand the duties and vocations as a church assembly, the lack of skills / skills of the church assembly in the field of horticultural agriculture and local village pig and chicken farming, lack of free time and lack of good cooperation.
\end{abstract}

Keywords: Economic Empowerment, Role of the Church Assembly, Toraja Church of Imanuel Botang Congregation

\begin{abstract}
Abstrak: Jemaat Imanuel Botang memiliki sumber daya baik Sumber Daya Manusia maupun sumber daya alamnya yang cukup melimpah, namun belum dikelola secara maksimal. Melihat kondisi tersebut peneliti tertarik melakukan penelitian peran majelis gereja dalam pemberdayaan ekonomi jemaat dengan memfokuskan penelitian pada kegiatan pemberdayaan ekonomi di bidang pertanian hortikultura dan peternakan ayam dan babi. Penelitian ini didesain menurut penelitian kualitatif. Penelitian kualitatif bertujuan untuk mengetahui peran majelis gereja dalam pemberdayaan ekonomi jemaat. Teknik pengumpulan data dilakukan melalui penelitian pustaka dan penelitian lapangan melalui pengamatan (observasi) dan wawancara (interview). Penelitian dilaksanakan di Jemaat Imanuel Botang dari bulan September sampai bulan November 2020. Hasil penelitian menunjukkan peranan Majelis Gereja dalam pemberdayaan adalah sebagai konsultan dan pemberdaya namun hal ini masih belum terealisasi oleh karena belum memahami secara utuh tugas dan panggilan sebagai majelis gereja, minimnya skill/ keterampilan majelis gereja pada bidang pertanian hortikultura dan peternakan babi dan ayam kampung lokal, kurangnya waktu luang dan kurangnya kerja sama yang baik.

Kata-kata Kunci: Gereja Toraja Jemaat Imanuel Botang, Pemberdayaan Ekonomi, Peran Majelis Gereja,
\end{abstract}

\begin{tabular}{llll}
\hline Article History : & Received: 15-09-2021 & Revised: 24-12-2021 Accepted:27-12-2021
\end{tabular}




\section{Pendahuluan}

Dalam kehidupan bergereja peran majelis gereja sangat dibutuhkan untuk memelihara keutuhan persekutuan dan menciptakan kesejahteraan bagi anggota jemaat dan untuk sesama manusia. Sebagaimana yang disampaikan pengamsal, (bdk. Amsal 11:14) bahwa, pemimpin/ majelis gereja sangatlah penting dalam suatu persekutuan atau gereja, bahkan dibutuhkan penasehat agar mencapai kesejahteraan (keselamatan). Dari sini kita dapat melihat pentingnya pemimpin dalam bergereja, agar terjalin keutuhan dan kesejahteraan bersama. Dalam keputusan Sidang Sinode Am Gereja Toraja (SSA XXIV) di Makale, majelis gereja adalah merupakan bagian dari pemimpin dalam kehidupan bergereja yang diberikan mandat untuk menjaga, memberikan pelayanan, mengarahkan dan mempraktekkan disiplin gerejawi berdasarkan Firman Tuhan. ${ }^{1}$

Untuk menciptakan kesejahteraan bagi anggota jemaat dan masyarakat secara luas banyak upaya yang bisa dilakukan. Salah satunya adalah melalui pelibatan anggota jemaat dalam usaha kreatif agar meningkatkan taraf hidup dalam bidang ekonomi Pemberdayaan adalah suatu cara dalam mengembangkan daya dengan memberikan dorongan dan meningkatkan pemahaman konsep sosial tentang potensi yang ada dan berusaha mengembangkannya. ${ }^{2}$ Pemberdayaan adalah usaha yang dilakukan secara terstruktur yang dimulai dengan mengenali potensi, mengembangkannya hingga mencapai tujuan yang diharapkan. Jadi dapat dimaklumi bahwa pemberdayaan ekonomi merupakan suatu pekerjaan terencana yang bertujuan untuk meningkatkan kesadaran masyarakat akan potensinya sehingga dapat dikembangkan untuk memenuhi setiap apa yang diperlukan dan dibutuhkan.

Dalam pemberdayaan banyak kegiatan yang bisa dilakukan masyarakat baik dari program pemerintah dan atau program gereja. Kegiatan tersebut bertujuan dalam rangka mendorong masyarakat untuk bisa lebih kreatif dan mandiri demi meningkatkan kesejahteran hidup. Dengan demikian, angka kemiskinan dan jumlah pengangguran bisa dapat ditekan.

Peranan majelis gereja sebagai pemimpin dibutuhkan dalam memberdayakan potensi yang dimiliki setiap anggota jemaat. Majelis gereja berperan dalam mengelolah dan mengatur organisasi dengan baik dan memecahkan masalah dengan mengikut sertakan orang-orang yang dipimpin dalam konteks kehidupan menggereja. Sebagaimana dalam kitab Yeremia yang menekankan bahwa seorang pemimpin perlu mengusahakan kesejahteraan jemaat demi kebaikan bersama (bdk. Yeremia 29 :7). Panggilan gereja

\footnotetext{
${ }^{1}$ Himpunan keputusan Sidang Sinode Am XXIV Gereja Toraja,.127

${ }^{2}$ Adito Bhinadi, Penangulangan Kemiskinan dan Pemberdayaan Masyarakat (Deepublish: Yogyakarta, 2017) 24.
} 
adalah mengusahakan kebutuhan jasmani dan rohani jemaat. Gereja hadir bukan hanya untuk meneguhkan umat-Nya, melainkan berguna bagi masyarakat secara menyeluruh di mana gereja itu ada. Gereja perlu memberdayakan setiap potensi yang dimiliki jemaatnya agar tidak terkungkung dalam masalah kemiskinan. Pada tiga jenis panggilan dalam hidup menggereja: yang pertama adalah bersekutu, yang kedua yakni bersaksi dan yang terakhir yakni melayani. Pemberdayaan anggota jemaat merupakan tugas panggilan gereja untuk berdiakonia (melayani). ${ }^{3}$

Pemberdayaan ekonomi dipandang penting untuk menjawab masalah yang muncul di tengah masyarakat secara umum dan gereja. Berdasarkan hasil pengamatan dari peneliti banyak dari anggota masyarakat dan jemaat yang masih menganggur. Mengacu pada data Badan Pusat Statistik (BPS) Republik Indonesia Februari 2019 tingkat pengangguran di Indonesia sebesar 5,01\% atau 6.816 .840 orang. ${ }^{4}$ Sedangkan data Badan Pusata Statistik (BPS) Kabupaten Tana Toraja tahun 2017 tingkat pengangguran di Kabupaten Tana Toraja sebesar 5,6\% atau 5.852 orang. ${ }^{5}$

Pemberdayaan ekonomi di masa pandemi Covid 19 saat sekarang ini sangat dibutuhkan. Pandemi Covid 19 sangat memberikan dampak negatif bagi pertumbuhan ekonomi jemaat. Sektor yang masih tetap tumbuh dan berkembang dimasa pandemi adalah sektor pertanian dan peternakan. Menurut Limbongan program pengembangan di bidang pertanian hortikultura dan peternakan perlu melibatkan anggota jemaat sebagai langkah dari pemberdayaan karena bidang ini cukup berhasil meningkatkan pendapataan anggota jemaat dimasa pandemi. Ini akan mempengaruhi dedikasi berupa persembahan dari anggota gereja. Seorang pemimpin dalam melaksanakan kegiatan pemberdayaan harus melihat kebutuhan anggota jemaat seperti pada masa pandemi Covid 19 ini, yakni bagaimana tetap menjaga ketahanan pangan.

Dengan melihat begitu banyaknya potensi yang dimiliki oleh jemaat Imanuel Botang Klasis Makale sehingga perlu dilakukan pemberdayaan ekonomi jemaat. Warga jemaat memiliki potensi sumber daya alam berupa lahan produktif yang tersedia dan sumber daya manusia yang berkualitas. Potensi Jemaat Imanuel Botang dari segi sumber daya alam adalah 1.) Lahan pertanian (kebun/pekarangan) seluas 15 Ha milik jemaat yang masih dapat ditingkatkan produktifitasnya karena pada saat sekarang ini belum dikelolah dengan optimal. 2.) Lahan pertanian (sawah) 3 Ha milik jemaat yang masih dapat ditingkatkan produktifitasnya karena pada saat sekarang ini belum dikelolah dengan optimal. 3.) Lahan pertanian (kebun/pekarangan) seluas 15 Ha milik jemaat yang

\footnotetext{
3Josef P.Widyatmadja, Yesus dan Wong Cilik, Praktis Diakonia Transformatif dan Teologi Rakyat di Indonesia (BPK. Gunung Mulia: 20017)48

4 Badan Pusat Statistik Republik Indonesia, https://www.bps.go.id/dynamictable/2020/02/ 19/1774/ tingkat-pengangguran- terbuka-tpt-menurut-provinsi-1986---2019.html, diakses 23 Februari 2020

${ }^{5}$ Badan Pusat Statistik Kabupaten Tana Toraja, https:// tatorkab.bps.go.id/statictable/2015/09/23/27/jumlah-angkatan-kerja-penduduk-bekerjapengangguran-tpak-dan-tp-di-kabupaten-tana-toraja-2011-2017.html, diakses 23 Februari 2020
} 
masih dapat ditingkatkan produktifitasnya karena pada saat sekarang ini belum dikelolah dengan optimal. 4.) Tersedianya pakan ternak yang dapat digunakan untuk mengembangkan usaha peternakan seperti kerbau, kambing, babi dan ayam yang selama ini masih dikelolah sebagai usaha sampingan. 5.) Adanya kayu/bambu bekas dari upacara adat yang dapat dijadikan sebagai kerajinan tangan yang selama ini hanya dibakar dan terbuang sama sekali. Sedangkan potensi sumber daya manusia adalah Jemaat Imanuel Botang terdiri dari 110 kepala keluarga dengan 550 jiwa. Jemaat pada usia lansia 66 tahun ke atas $18 \%$ atau 99 jiwa usia produktif 18 - 65 tahun $52 \%$ atau 286 jiwa, balita dan anak-anak 1 - 17 tahun 30\% atau 165 jiwa. Usia produktif di jemaat Imanuel Botang terdiri dari PNS 25 orang, karyawan swasta 38 orang, honorer 13 orang, wiraswasta 42 orang dan petani, tukang ojek, sopir 61 orang. Hal ini berarti ada 37,7\% atau 107 jiwa usia produktif di Jemaat Imanuel Botang yang siap untuk diberdayakan.

Maka dari itu, berdasarkan fenomena tersebut yakni potensi Sumber Daya Alam Jemaat Imanuel Botang yang melimpah berupa lahan produktif namun tidak dikelola demi kesejahteraan jemaat dan tersedianya Sumber Daya Manusia yakni sebanyak 37,7\% atau 107 jiwa usia produktif di Jemaat Imanuel Botang namun tidak diberdayakan. Sementara itu, ekonomi jemaat menurut data yang diperoleh dari pre-observasi, wawancara, dan data dokumen gereja menunjukkan keadaan ekonomi Imanuel Botang secara umum berada pada garis ekonomi menengah ke bawah. Beberapa peneliti telah mengkaji tentang peran gereja dalam pemberdayaan jemaat. Sumbung, dkk menemukan bahwa Pola pengembangan masyarakat yang dilakukan oleh GMIM (Gereja Masehi Injili di Minahasa) adalah melalui BLPT (Training Center) Kaaten - Tomohon berdasarkan pengolahan kelapa-kayu telah berhasil dalam meningkatkan kesejahteraan masyarakat. Secara umum, pola yang dilakukan oleh GMIM adalah pemberdayaan ekonomi. Dalam menjalankan usahanya, BLPT melibatkan setiap workfoce siswa drop-out dari sekolah atau tidak menyelesaikan sekolah tinggi, sehingga berpotensi meningkatkan pendapatan masyarakat sekitar, mengurangi jumlah putus sekolah, meningkatkan pengembangan bisnis kreatif, mengurangi kemiskinan dan pengangguran, dan meningkatkan pendapatan untuk kas GMIM. ${ }^{6}$ Mengga menemukan bahwa fungsi diakonia Gereja dan kebijakan ekonomi sinode GMIT, jelas sekali bahwa Gereja tidak hanya berperan dalam bidang spiritual saja, tetapi juga dalam bidang sosial. Peran-peran yang dilakukan Gereja seharusnya selalu berkelanjutan, serta melibatkan pihak luar sebagai patner Gereja dalam menjalankan peran sosialnya. ${ }^{7}$ Pasande menemukan bahwa menemukan keragaman kewirausahaan, sehingga tidak ada yang sama persis dengan yang lain. Karena itu, Gereja

\footnotetext{
${ }^{6}$ Grace Sumbung, dkk. Peran gereja dalam peningkatan ekonomi masyarakat di Tomohon Sulawesi Utara 2012. 5

7 Mengga. Peran gereja terhadap pemberdayaan ekonomi jemaat di jemaat GMIT Betania Oetaman Desa Linamnutu. Universitas Kristen Satya Wacana 2013. 4
} 
harus aktif baik dalam pemenuhan kebutuhan rohani maupun jasmani. 8 Dengan demikian, tujuan penelitian ini adalah untuk mengetahui Peran Majelis Gereja dalam Pemberdayaan Ekonomi di Jemaat Imanuel Botang.

\section{Metode Penelitian}

Metode penelitian adalah proses yang pengumpulan data dan penyelidikan terhadap data yang sudah diperoleh dengan menggunakan cara tertentu. ${ }^{9}$ Metode yang diaplikasikan dalam kajian ini adalah metode penelitian kualitatif dengan pendekatan penelitian kepustakaan (library research) yang mengumpulkan teori-teori dari buku yang tentunya memiliki hubungan dengan pembahasan dalam penelitian ini. Kemudian penelitian melalui lapangan (field research) yang dilakukan melalui pengamatan secara langsung dan melakukan wawancara kepada beberapa narasumber yang memiliki hubungan langsung dengan topik yang diteliti.

Pengumpulan data dalam penelitian ini ini menggunakan 2 instrumen yaitu observasi dan wawancara. Pada tahapan observasi peneliti turun ke lapangan melakukan pengamatan penelitian dengan mengidentifikasi peran majelis gereja dalam pemberdayaan ekonomi jemaat. Sedangkan pada tahapan wawancara peneliti turun langsung ke lapangan dengan melakukan wawancara kepada anggota jemaat, majelis gereja (diaken) dan pendeta. Hal tersebut bertujuan untuk mengetahui bagaimana peran majelis gereja dalam pemberdayaan ekonomi di Jemaat Imanuel Botang.

\section{Hasil dan Pembahasan}

Setiap pemimpin dalam "kepemimpinannya" memiliki peran yang ditugaskan kepadanya untuk mencapai tujuan yang diinginkan. Peran seorang pemimpin diimplementasikan dalam dimensi perencanaan organisasi atau komunitas yang komprehensif, pemimpin mengharapkan kepekaan terhadap perkembangan sehingga dapat mengatasi hambatan yang muncul, pemimpin memberikan contoh yang baik kepada bawahannya, mengawasi, membuat keputusan secara individu atau kelompok, dan memotivasi anggota. ${ }^{10}$

Sebagai pemimpin, majelis gereja tidak hanya berfungsi dalam memberi dampak, tetapi juga menjadi inspirator dan petunjuk serta berupaya memberi dorongan bagi anggota jemaat. Jadi, pemimpin wajib memiliki kapabilitas lebih baik dan tinggi tarafnya dari pada mereka yang dipimpinnya. Pemimpin yang sebenar-benarnya itulah yang menjamin keberhasilannya dalam memimpin bawahannya, pemimpin memiliki ciri dan kemampuan seperti kecerdasan spiritual, intelektual, dan emosional. Pemimpin seperti

\footnotetext{
8 Purnama Pasande, Peran gereja dalam pengembangan program kewirausahaan di era digital. Visio Dei jurnal teologi kristen 2019.

9 J.R. Raco, Metode Penelitian Kulalitatif, (Gramedia: Jakarta 2010)17

10 Susanto, Strategic Leadership (Gramedia: Jakarta 2019),3
} 
itu adalah pemimpin yang dapat membimbing kehidupan masyarakat yang lebih baik. ${ }^{11}$ Dalam membimbing dan mengarahkan anggota jemaat ke arah yang lebih baik maka perlu dilakukan pemberdayaan dalam bidang ekonomi. Pemberdayaan adalah pekerjaan terencana yang bertujuan membantu masyarakat dalam mengembangkan segala potensi mereka menuju kemakmuran. Pemberdayaan mengubah cara berpikir masyarakat dari perilaku malas menjadi kerja keras, dan dari ketergantungan menjadi kemandirian prioritas. Terminologi ekonomi mencatat bahwa pemberdayaan merupakan proses mengembangkan dan mengupayakan masyarakat tidak mampu melalui pemberian bantuan baik modal dan dukungan lainnya menuju kesejahteraan. ${ }^{12}$

Dalam pemberdayaan ekonomi salah satu persoalannya adalah bagaimana cara memanfaatkan sumber daya alam untuk meningkatkan kesejahteraan. Dalam hal pemanfaatan sumber daya alam dalam pemberdayaan, peran lahan sebagai basis berbagai hasil dan sumber daya pertanian tidak akan jauh. Saat memproduksi pangan (pertanian), bahan baku, perikanan, peternakan dan kehutanan, kita secara langsung melihat dan merasakan peran lahan. Pemberdayaan ekonomi yang akan diuraikan dalam pembahasan ini dan mendapat perhatian khusus adalah Pertanian Hortikultura dan Peternakan.

Berkebun atau holtikultura berasal dari istilah hortus (hortikultura), budidaya berasal dari perpaduan kata kebun dan budaya. terminologi ini diaplikasikan untuk menggambarkan pola produksi yang memenuhi kebutuhan sehari-hari seperti sayuran, buah dan tanaman hias. Berkebun adalah penanaman tanaman di sekitar taman atau rumah atau pekarangan. Tanaman berkebun berupa tanaman hias, buah dan sayur. ${ }^{13}$ Produk hortikultura khususnya buah dan sayur merupakan produk pertanian yang sangat dibutuhkan masyarakat. Tanaman hortikultura yang akan dibahas di sini adalah sayuran.

Pemberdayaan di bidang pertanian hortikultura dipandang penting karena selain untuk konsumsi rumah tangga, petani juga dapat menjualnya sebagai pendapatan ekonomi keluarga. Dari segi kebutuhan konsumsi produk hortikultura yang tinggi, hal ini merupakan sebuah peluang pasar untuk melakukan budidaya tanaman ini.

Berdasarkan hasil pengamatan yang dilakukan di Pasar Sentral Makale Kabupaten Tana Toraja, sayur-sayuran yang masuk di wilayah Kabupaten Tana Toraja kebanyakan dari Palopo dan Enrekang yang diangkut menggunakan mobil pick up dan motor yang dipasarkan sampai keliling ke kampung-kampung/pelosok. Jika dicermati, sayuran yang

\footnotetext{
${ }^{11}$ Simplesius Sandur. Filsafat Politik \& Hukum THOMAS AQUINAS, (Yogyakarta: Kanisius, 2019), 208.

${ }^{12}$ Totok Mardikanto, Yesus Fasilitator Pemberdayaan Masyarakat, ( Solo, Prima Theresia Presindo, 2005) 11

${ }^{13}$ Inggit Winarni, Hortikultura. In: Ruang Lingkup dan Perkembangan Hortikultura. Universitas Terbuka, Jakarta, 2008 pp. 1-43.
} 
potensial untuk dikembangkan di wilayah Tana Toraja seperti daun ubi kayu, daun mayana, nangka, sawi, bayam, kacang panjang, buncis dan lain sebagainya kini sudah dibawa masuk ke Toraja. Tawaran: Potensi sumber daya alam di Tana Toraja sangat mendukung bagi pengembangan produk pertanian tersebut.

Peraturan Menteri Keuangan Republik Indonesia Nomor 107/PMK.05/2020 entang Mekanisme Pelaksanaan dan Pertanggungjawaban atas Pajak Ditanggung Pemerintah dalam Rangka Penanganan Pandemi Corona Virus Disease 2019 menyatakan bahwa Pemerintah Indonesia mendukung penuh pertanian hortikultura melalui alokasi anggaran tiap tahun yang selalu disediakan, pembangunan infrastruktur pertanian dan penyediaan benih dan pupuk. Di masa pandemi Covid 19 sekarang ini untuk tetap menjaga ketahanan pangan pemerintah mulai dari pusat hingga daerah mengajak masyarakat memanfaatkan lahan pekarangan rumah untuk menanam sayur-sayuran.

Peternakan merupakan usaha mengembang biakkan hewan demi memenuhi kebutuhan pangan (daging), susu, serta telur yang memiliki kualitas yang baik sesuai standar kesehatan yang ada. Dengan adanya usaha peternakan maka dapat meningkatkan penghasilan para peternaknya, negara dibantu melalui penerimaan devisa, serta membantu para pengangguran dalam mendapatkan pekerjaanya. ${ }^{14}$ Saat ini, pemerintah berupaya dalam membantu peternak untuk lebih sejahtera dengan mengutamakan hasil ternak mereka melalui upaya pengembangan ternak lokal.

Potensi ternak dengan permintaan meningkat dan bernilai jual tinggi di Tana Toraja adalah ayam kampung lokal dan babi. Sebagaimana diketahui ternak ayam kampung dan babi di Tana Toraja merupakan ternak selalu dibutuhkan baik di acara rambu tuka' dan rambu solo'. Hal ini menjadi peluang pasar untuk mengembangkan usaha peternakan di Tana Toraja.

Dari pengamatan yang dilakukan di Pasar Sentral Makale, ternak seperti babi dan ayam kampung kebanyakan didatangkan dari luar Toraja yakni dari Sulawesi Tengah dan Luwu. Sementara di Tana Toraja, secara khusus di Jemaat Imanuel Botang adalah wilayah yang sangat potensial untuk dikembangkan usaha peternakan ini karena pertama didukung dari sumber daya alam seperti ketersedia bahan makanan (pakan lokal), kedua aspek pemasaran yang masih sangat luas dengan permintaan pasar yang semakin meningkat.

Ada beberapa dimensi yang menentukan pemberdayaan ekonomi. Salah satu pertimbangan untuk menjadi seorang pemberdayaan atau pemimpin adalah dengan memainkan peran yang baik. Peran pemimpin yaitu pemimpin adalah menyusun rencana yang komprehensif bagi organisasi atau masyarakat, pemimpin diharapkan peka terhadap perkembangan. Atau untuk membuat keputusan dalam kelompok, pemimpin harus mendorong dan memotivasi anggotanya. Adapun beberapa peran yang harus

${ }^{14}$ Saragi.B, Agribisnis Berbasis Peternakan Kumpulan Pemikiran (IPB. Bandung 2000) 45 
dijalankan oleh pemberdaya atau pemimpin yakni: ${ }^{15}$

1. Bertindak sebagai konsultan; meliputi upaya membangun hubungan antara klien dan sumber daya yang tersedia sehingga dapat meningkatkan rasa percaya diri dan memiliki keterampilan untuk menyelesaikan masalah dan tantangan yang ada. Pekerjaan ini juga bertujuan untuk meningkatkan kemandirian klien agar dapat mengontrol hidupnya.

2. Sebagai pemberi otorisasi yang sensitif, tanggung jawabnya mencakup membantu klien dalam memperoleh pengetahuan yang diperlukan untuk mengendalikan hidup mereka. Tindakan ini erat kaitannya dengan pemberdayaan setiap orang agar dapat mengenali dan mengenali kekuatan diri sendiri dan kekuatan orang lain.

3. Berlaku sebagai guru dan pelatih, di mana dapat bertindak sebagai petugas lapangan maupun bertindak sebagai pekerja sosial yang mengatur proses belajar klien untuk menemukan solusi atas permasalahan yang mereka hadapi. Petugas lapangan bertugas untuk mengajar komunitas untuk berjuang dalam menghadapi segala rintangan dan ketidakmampuan yang dihadapi.

4. Bertindak sebagai penghubung atau jaringan. Ini mengacu pada pemahaman bahwa pelanggan adalah orang yang memiliki keinginan kuat untuk mencapai tujuan dari kegiatan yang diotorisasi. Oleh karena itu, para pemberdaya harus mampu menghubungkan masyarakat berdaya dengan pihak lain yang diyakini mampu berbagi sejarah, masalah, dan kendala yang sama, sehingga dapat menjadi rujukan bagi masyarakat berdaya.

Dalam menjalankan peran tersebut, otorisasi harus dapat melihat beberapa hal yang dapat dibedakan. Hal pertama yang harus diberdayakan adalah keluarga. Pemberdayaan keluarga merupakan upaya strategis untuk menentukan stabilitas dan keberlanjutan rencana pembangunan. Oleh karena itu, arah transformasi sosial diharapkan dapat menumbuhkan pengetahuan, keterampilan dan motivasi keluarga untuk meningkatkan kualitas sumber dayanya. Strategi dasar pembinaan kemampuan keluarga melalui proses pemberdayaan dan pemberdayaan adalah dengan mengintervensi sistem sosial yang ada. Intervensi akan mengarah pada pengembangan sektor sosial yang terkait langsung dengan masalah sosial. Artinya unsur pemberdayaan keluarga harus dipengaruhi melalui proses pemberdayaan agar keluarga dapat berperan lebih besar melalui interaksi. ${ }^{16}$

15J.A.B, Lee, The Empowerment Approach to Social Work Practise: Building a Beloved Community, (New York, Columbia University Press, 2001).

${ }^{16}$ Adi Fahrudin, Pemberdayaan Partisipasi dan Penguatan Kapasitas Masyarakat, (Bandung, Humaniora, 2012), 5. 
Vesto Proklamanto Magany selaku Sekum Yakoma PGI mengemukakan pada Sidang Raya XVI Persekutuan Gereja-Gereja di Indonesia (SR XVI PGI) pemberdayaan ekonomi gereja dan pengentasan kemiskinan tidak lagi membahas Alkitab atau teori spiritual ketika mencari solusi untuk kemiskinan. ${ }^{17}$ Gereja terus berupaya dalam berkonsolidasi dengan pemerintah agar kemiskinan menjadi bahan kajian dan rekomendasi untuk segera dituntaskan. Karenanya, pemberdayaan jemaat secara khusus perlu terus digalakkan. Pemberdayaan ekonomi kepada jemaat adalah segala upaya yang dilakukan dalam rangka meningkatkan taraf hidup jemaat melalui usaha atau kegiatan yang sifatnya berkelanjutan. Diakonia dalam tradisi gereja secara sempit diwujudkan dalam kegiatan-kegiatan yang mendukung kemiskinan, penelantaran, dan penyakit. Dalam arti yang lebih luas, tujuan pelayanan diakonia adalah untuk memungkinkan orang menjalani kehidupan yang utuh. Salah satu uraian tugas diaken Gereja Toraja adalah dengan antusias menyelenggarakan pelayanan diaken untuk mewujudkan kesejahteraan anggota gereja dan sesama manusia yang membutuhkan. ${ }^{18}$

Dalam mejalankan perannya Gereja Toraja terpanggil dalam memikirkan kesejahteraan umatnya dan masyarakat secara luas. Badan Pekerja Sinode Gereja Toraja (BPS-GT) merangkum kegiatan pemberdayaan ekonomi melalui program untuk meningkatkan partisipasi gereja dalam pengelolaan sumber daya ekonomi komunitas. Berdasarkan Himpunan Keputusan Sidang Sinode Am XXIV Gereja Toraja 2016, dalam menindak lanjuti program ini upaya-upaya yang akan dilakukan adalah: ${ }^{19}$

1. Peningkatan pemahaman dan kesadaran warga gereja akan potensi yang dimilikinya dan keharusan untuk mempertanggungjawabkan pengelolaan potensi tersebut kepada Tuhan, selaku Pemberi mandat kepada manusia untuk mengelolah bumi dan ciptaan Allah lainnya .

2. Peningkatan etos kerja, kreativitas dan produktivitas warga jemaat, melalui kegiatan :

a. Penyelenggaraan pelatihan entrepreneurship, yang bekerja sama dengan pemerintah dan atau lembaga terkait lainnya.

b. Penyelenggaraan lomba cipta "kerajinan tangan" (mengubah bahan bekas menjadi benda yang bernilai ekonomi), bekerja sama dengan pemerintah khususnya Dinas Perindustrian dan Ekonomi Kreatif.

c. Pelaksanaan pelatihan-pelatihan usaha "kerajinan tangan" bekerja sama dengan pemerintah khususnya Dinas Perindustrian dan Ekonomi Kreatif.

d. Pemanfaatan sumber-sumber ekonomi oleh warga masyarakat dan kelompok tani, melalui :

${ }^{17}$ https://pgi.or.id/sr-xvi-pgi-pemberdayaan-ekonomi-jemaat-tak-lagi-bicara-teori/ (diakses 28 Oktober 2020)

18Tata Gereja Gereja Toraja, Rantepao 2008,71

${ }^{19}$ Sinode Gereja Toraja, Himpunan Keputusan Sidang Sinode Am XXIV Gereja Toraja 2016,289- 
1) Pelaksanaan pelatihan mengenai tatacara bertani dan beternak dengan baik yang bekerja sama dengan pemerintah.

2) Membangun percontohan untuk aneka kegiatan produktif, khususnya di bidang pertanian, peternakan, perkebunan dan perikanan, yang diselenggarakan oleh Yayasan Tallulolona bekerja sama dengan pemerintah dan masyarakat.

3) Pemberian dukungan dan fasilitasi bagi warga agar dapat memanfaatkan secara optimal dana-dana dari pemerintah untuk pengembangan ekonomi.

4) Menyelenggaraan lomba-lomba optimalisasi pemanfaatan lahan dan pelestarian lingkungan yang bekerjasama dengan pihak pemerintah.

Badan Pekerja Sinode Wilayah III Makale (BPS-WIII Makale ) bidang II juga merangkum program pemberdayaan ekonomi. Dalam program ini diagendakan tentang peningkatan pemahaman warga Gereja Toraja Wilayah III Makale akan potensi yang dimilikinya, dengan mengembangan kesadaran, kemampuan dan kemauan untuk mendayagunakan potensi tersebut. Program ini bertujuan untuk mendorong warga jemaat untuk memanfaatkan potensi dan tawaran bantuan permodalan dari pihak lain (bank) untuk kepentingan usaha produktif, dan bukan untuk kepentingan konsumtif.

Tujuan dari upaya Gereja untuk memperkuat ekonominya adalah untuk mencari peluang kerja bagi orang-orang yang di-PHK atau menganggur, untuk mencari keterampilan dan pengetahuan dalam modal kerja, untuk mencari pengembangan bisnis rumahan untuk penghasilan tambahan dan kegiatan produktif, dan untuk mendukung setiap upaya untuk mengembangkan ekonomi dalam semangat kasih menuju kemandirian.

Ciri-ciri anggota jemaat yang mandiri yakni:

a) Dapat mengidentifikasi setiap masalah yang dihadapi, merumuskan dan menetapkan prioritas.

b) Mampu menemukan solusi alternatif untuk masalah yang dihadapi,

c) Mampu mengatur diri sendiri sebagai cara untuk memecahkan masalah bersama,

d) Mampu merumuskan aturan main, nilai dan norma, aturan ini dapat disepakati bersama dan dipatuhi setelah disusun.

e) Dapat memperluas kerjasama melalui kemitraan yang setara.

Dalam pembahasan ini akan dibahas mengenai peran majelis gereja dalam pemberdayaan ekonomi jemaat. Dalam hal ini peneliti melakukan pengamatan, wawancara dengan majelis dan wawancara dengan jemaat. Untuk mengetahui mengenai peran majelis gereja dalam pemberdayaan ekonomi jemaat berikut hasil obeservasi dan wawancara. 


\begin{tabular}{|c|c|c|c|}
\hline No. & Peranan & $\begin{array}{l}\text { Jumlah } \\
\text { Majelis Gereja } \\
\text { yang terlibat }\end{array}$ & $\begin{array}{l}\text { Deskripsi hasil observasi dan wawancara } \\
\text { dengan narasumber }\end{array}$ \\
\hline 1. & Konsultan & 1 orang & $\begin{array}{l}\text { Menerapkan peran sebagai konsultan } \\
\text { (mendampingi anggota jemaat) }\end{array}$ \\
\hline 2. & Pemberdaya & 2 orang & $\begin{array}{l}\text { Menerapkan peran sebagai pemberdaya } \\
\text { (memberikan bantuan benih kepada anggota } \\
\text { jemaat) }\end{array}$ \\
\hline 3. & Guru dan Pelatih & - & $\begin{array}{l}\text { Selama ini belum ada yang menerapkan } \\
\text { peranan sebagai guru dan pelatih }\end{array}$ \\
\hline 4. & $\begin{array}{l}\text { Penghubung } \\
\text { Jaringan Kerja }\end{array}$ & - & $\begin{array}{l}\text { Selama ini belum ada yang menerapkan } \\
\text { peranan sebagai penghubung jaringan kerja. }\end{array}$ \\
\hline
\end{tabular}

Tabel 1 Peran Majelis Gereja Toraja Jemaat Imanuel Botang Dalam Pemberdayaan Ekonomi Anggota Jemaat

Penguatan jemaat melalui peningkatan kapabilitas ekonomi mereka sangat esensial karena dapat menurunkan angka pengangguran dan meningkatkan motivasi. Belakangan ini, kita bisa melihat jumlah pengangguran yang meningkat secara signifikan. Pasalnya, jumlah tenaga kerja tidak sebanding dengan jumlah lapangan kerja yang tersedia. Kehadiran para pemimpin di gereja diharapkan dapat membawa perubahan menjadi lebih baik di dalam jemaat. Oleh karena itu, pemimpin khususnya para majelis diharapkan memiliki potensi yang lebih besar dari pada yang dipimpinnya (jemaat). Agar dapat membawa perubahan, diharapkan peran pemimpin secara aktif.

Peran pemimpin (majelis gereja) telah di atur dan disepakati bersama dalam tata gereja Gereja Toraja. Salah satu uraian tugas majelis gereja (diaken) adalah melaksanakan pelayanan diakonia dengan belas kasih dan iklas untuk memastikan kesejahteraan anggota jemaat yang membutuhkan. Pada uraian tugas ini begitu jelas di ungkapakan tugas/peran majelis gereja (diaken) dalam membimbing dan mengarahkan anggota jemaat kepada kesejahteraan hidup. Namun pada dasarnya konsep ini belum berjalan sebagaimana yang diharapkan di jemaat Imanuel Botang. Dengan merujuk pada data tersebut, pada dasarnya Jemaat Imanuel Botang memiliki potensi Sumber Daya Manusia yakni sebanyak 26 Majelis Gereja yang memiliki potensi dalam pengembangan ekonomi jemaat melalui usaha peternakan dan hortikultura. Dalam bidang diakonia, ada sebanyak 8 orang majelis yang bertugas untuk melayani jemaat. Namun hal ini sekaligus menjadi titik lemahnya karena belum ada dari majelis gereja yang memiliki kemampuan dan keilmuan dalam bidang peternakan dan hortikultura. Sehingga kondisi ekonomi jemaat Imanuel Botang secara umum tidak mengalami peningkatan. Dalam pemberdayaan 
ekonomi secara khusus pada bidang tanaman hortikultura dan peternakan babi dan ayam kampung belum terlalu nampak peran majelis gereja (Tabel 1). Hal ini terjadi oleh karena beberapa hal; pertama para pemimpin/ majelis gereja belum memahami dengan jelas uraian tugas dan tanggung jawabnya, kedua para pemimpin/ majelis gereja dalam menjalankan kepemimpinannya kekurangan skill dan pengetahuan pada bidang tersebut dan juga minimnya waktu luang majelis gereja untuk mendampingi anggota jemaat.

\section{Kesimpulan}

Dengan merujuk pada data hasil dan pembahasan penelitian mengenai peran majelis gereja dalam pemberdayaan ekonomi jemaat Imanuel Botang, peneliti menyimpulkan bahwa peranan Majelis Gereja dalam pemberdayaan adalah sebagai konsultan dan pemberdaya namun hal ini masih belum terealisasi oleh karena belum memahami secara utuh tugas dan panggilan sebagai majelis gereja, minimnya skill/ keterampilan majelis gereja pada bidang pertanian hortikultura dan peternakan babi dan ayam kampung lokal, kurangnya waktu luang dan kurangnya kerja sama yang baik.

Terkait hasil penelitian ini, peneliti mengajukan saran untuk diperhatikan oleh majelis gereja dalam rangka mengoptimalkan peran dalam pemberdayaan ekonomi jemaat: Perlu memahami secara utuh tugas dan panggilan majelis gereja dalam pelayanan dan mengembangkan skill/ keterampilan pada bidang pertanian dan peternakan edukasi secara khusus dalam bidang pertanian dan peternakan.

\section{Referensi}

Adito, Bhinadi. "Penangulangan Kemiskinan dan Pemberdayaan Masyarakat". Yogyakarta: Deepublish, 2017.

Chabib, Soleh. "Dialektika Pembangunan Dengan Pemberdayaan”. Bandung: Fokusmedia, 2014.

Fahrudin. "Pemberdayaan Partisipasi dan Penguatan Kapasitas Masyarakat". Bandung: Humaniora, 2012.

Himpunan keputusan Sidang Sinode Am XXIV Gereja Toraja

Josef, P., Widyatmadja. "Yesus dan Wong Cilik, Praktis Diakonia Transformatif dan Teologi Rakyat di Indonesia". Yogyakarta: Gunung Mulia, 2017.

J.R., Raco. "Metode Penelitian Kulalitatif “. Jakarta: Gramedia, 2010.

J.A.B, Lee. "The Empowerment Approach to Social Work Practise: Building a Beloved Community". New York: Columbia University Press, 2001.

Moh, Nasir. “Metodologi Penelitian”. Jakarta: Ghalia Indonesia, 2009.

Moh, Satari. "Metode Penelitian Kualitatif “. Bandung: Alfabeta, 2009.

Sinode Gereja Toraja, 2020 Himpunan keputusan Sidang Sinode Am XXIV Gereja Toraja 
Saragi, B. “Agribisnis Berbasis Peternakan Kumpulan Pemikiran”. Bandung: IPB, 2000.

Simplesius, Sandur. "Filsafat Politik \& Hukum THOMAS AQUINAS". Yogyakarta: Kanisius, 2019.

Susanto. "Strategic Leadership". Jakarta: Gramedia, 2019.

Totok, Mardikanto. "Yesus Fasilitator Pemberdayaan Masyarakat", Solo: Prima Theresia Presindo, 2005.

Badan Pusat Statistik Republik Indonesia, https://www.bps.go.id/dynamictable/2020/02/ 19/1774/ tingkat-pengangguranterbuka-tpt-menurut-provinsi-1986---2019.html, diakses 23 Februari 2020

Badan Pusat Statistik Kabupaten Tana Toraja, https:// tatorkab.bps.go.id/statictable/2015/09/23/27/jumlah-angkatan-kerja-pendudukbekerja-pengangguran-tpak-dan-tp-di-kabupaten-tana-toraja-2011-2017.html, diakses 23 Februari 2020

Inggit, Winarni. "Hortikultura. dalam: Ruang Lingkup dan Perkembangan Hortikultura. Jakarta: Universitas Terbuka, 2008.

Data statistik Jemaat Imanuel Botang tahun 2020.

Grace Sumbung, dkk. Peran gereja dalam peningkatan ekonomi masyarakat di Tomohon Sulawesi Utara 2012.

Mengga. Peran gereja terhadap pemberdayaan ekonomi jemaat di jemaat GMIT Betania Oetaman Desa Linamnutu. Universitas Kristen Satya Wacana 2013.

Purnama Pasande, Peran gereja dalam pengembangan program kewirausahaan di era digital. Visio Dei jurnal teologi kristen 2019. 